\title{
NO AND C OXIDATION WITH PT RECOVERED FROM SPENT CATALYTIC CONVERTERS
}

\author{
N. Russo*, J. C. Caroca, D. Fino, S. Bensaid, G. Saracco and V. Specchia \\ Materials Science and Chemical Engineering Department, Politecnico di Torino, \\ C.so Duca degli Abruzzi 24, 10129 Torino, Italy. e-mail: nunzio.russo@polito.it
}

\section{Summary}

A selective recovery process of recovery platinum from spent automotive catalytic converters using a strong basic ion exchange resin was developed. Recovered Pt was characterized by FESEM-EDS technique and used for the preparation of $2 \mathrm{wt} \% \mathrm{Pt} / \mathrm{Al}_{2} \mathrm{O}_{3}$ catalyst powder samples. Catalytic activity comparison between catalysts based on recovered platinum and commercial Pt/ $\mathrm{Al}_{2} \mathrm{O}_{3}$ catalysts showed that the $2 \mathrm{wt} \% \mathrm{Pt}\left(\right.$ recovered) $/ \mathrm{Al}_{2} \mathrm{O}_{3}$ exhibited a slightly higher peak combustion temperature $\left(\mathrm{Tp}=561^{\circ} \mathrm{C}\right)$ compared with the commercial $2 \mathrm{wt} \% \mathrm{Pt} / \mathrm{Al}_{2} \mathrm{O}_{3}\left(\mathrm{Tp}=555^{\circ} \mathrm{C}\right)$. Shifting our attention towards the $\mathrm{NO}$ oxidation to $\mathrm{NO}_{2}$, both catalysts showed a similar performance, reaching the highest conversion $(\sim 61 \%)$ at $310^{\circ} \mathrm{C}$ with no production of nitrous oxide.

Keywords

Sustainability, Environmental Reaction Engineering.

\section{Introduction}

Automotive catalysts today make almost $50 \%$ of the global demand for the Platinum Group Metals (PGM) due to emission limits enforced by international legislation. The catalysts contain either platinum or platinum/palladium combinations to oxidize carbon monoxide (CO) and unburnt hydrocarbons (HC) to carbon dioxide $\left(\mathrm{CO}_{2}\right)$ and water $\left(\mathrm{H}_{2} \mathrm{O}\right)$. The recovery of these precious metals present in spent automobile catalytic converters [1] is an important topic not only from the economic point of view but also for recycling rare natural resources. The main purpose of this work is to develop a selective recovery process of recovery platinum from a spent catalytic converter using a strong basic ion exchange resin and then to carry out catalytic activity comparison between catalysts based on recovered platinum from spent catalytic converters $\left(\mathrm{Al}_{2} \mathrm{O}_{3}\right.$ as a support $)$ and commercial $\mathrm{Pt} / \mathrm{Al}_{2} \mathrm{O}_{3}$ catalysts.

\section{Materials and Methods}

For Pt recovering, 250g of a spent catalytic converter was treated with 1 liter of aqua regia $\left(\mathrm{HCl} / \mathrm{HNO}_{3}=3: 1\right)$ as leaching solution [2]. With continued stirring, the mixture was heated at $70^{\circ} \mathrm{C}$ for $3 \mathrm{~h}$. The obtained solution was then processed by means of the Column ion-exchange procedure [3] to recover the platinum (Fig 1). During the

\footnotetext{
${ }^{*}$ To whom all correspondence should be addressed
}

process, absorption atomic analysis was carried out to measure the platinum concentration in the solution.

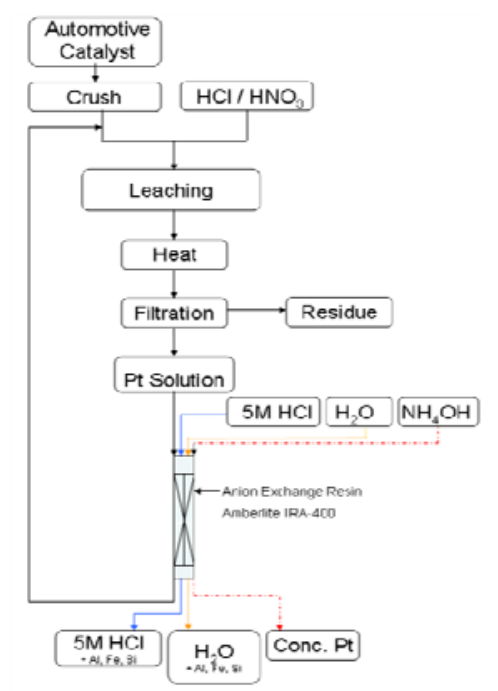

Figure 1: Process for platinum recovery

Two 2wt\% $\mathrm{Pt} / \mathrm{Al}_{2} \mathrm{O}_{3}$ catalyst powder samples were synthesized via incipient wetness impregnation IWI [5]. The first sample was prepared by using the recovered platinum, whereas the second one was prepared by using 
an aqueous solution of hydrogen hexachloroplatinate (IV) provided by Sigma-Aldrich. The activity of the prepared catalysts towards the carbon oxidation was analyzed by means of Temperature-Programmed Combustion (TPC), carried out in a fixed-bed micro-reactor under standard operating conditions (air flow rate of $50 \mathrm{Nml} \cdot \mathrm{min}^{-1}$, carbon/catalyst $1: 9$ mass basis, $\mathrm{W} / \mathrm{F}=0.05 \mathrm{~g} \cdot \mathrm{s} \cdot \mathrm{cm}^{-3}$, GHSV of $9,000 \mathrm{~h}^{-1}$, heating rate of $5{ }^{\circ} \mathrm{C} / \mathrm{min}$ ). The outlet gas was monitored by a $\mathrm{CO} / \mathrm{CO}_{2}$ NDIR analyzer (ABB).

The same catalysts were also tested for the oxidation of NO towards $\mathrm{NO}_{2}$ with the same apparatus according to the following conditions, gas mixture: 93 ppmv NO; 15 vol.\% $\mathrm{O}_{2}, \mathrm{~N}_{2}=$ balance; flow rate of $350 \mathrm{Nml} \cdot \mathrm{min}^{-1}, \mathrm{~W} / \mathrm{F}=$ $0.02 \mathrm{~g} \cdot \mathrm{s} \cdot \mathrm{cm}^{-3}$, GHSV of $40,000 \mathrm{~h}^{-1}$, heating rate of 5 ${ }^{\circ} \mathrm{C} / \mathrm{min}$ ). The outlet gas was monitored by both a $\mathrm{NO} / \mathrm{NO}_{2}$ chemiluminescence analyzer (Eco Physics) and a $\mathrm{N}_{2} \mathrm{O}$ NDIR analyzer (ABB).

\section{Results and discussion}

After the leaching with aqua regia, a solution containing an elevated concentration of platinum (640 ppm) and several undesirable compounds ( $\mathrm{Al}, \mathrm{Fe}, \mathrm{Si}$, among others) was obtained. The column ion-exchange procedure with a strong anionic resin ( Amberlite IRA - 400) was used to separate the platinum complex $\left[\mathrm{PtCl}_{6}\right]^{2-}$, recovering $71 \%$ of the present platinum, with high pureness. The SEM analysis carried out with the BSE detector showed a ceramic matrix of $\mathrm{Al}_{2} \mathrm{O}_{3}$ with platinum cluster having an average diameter of $10-20 \mathrm{~nm}$ finely dispersed onto the surface for the $2 \mathrm{wt} \% \mathrm{Pt}\left(\right.$ recovered) $/ \mathrm{Al}_{2} \mathrm{O}_{3}$ (Fig. 2).

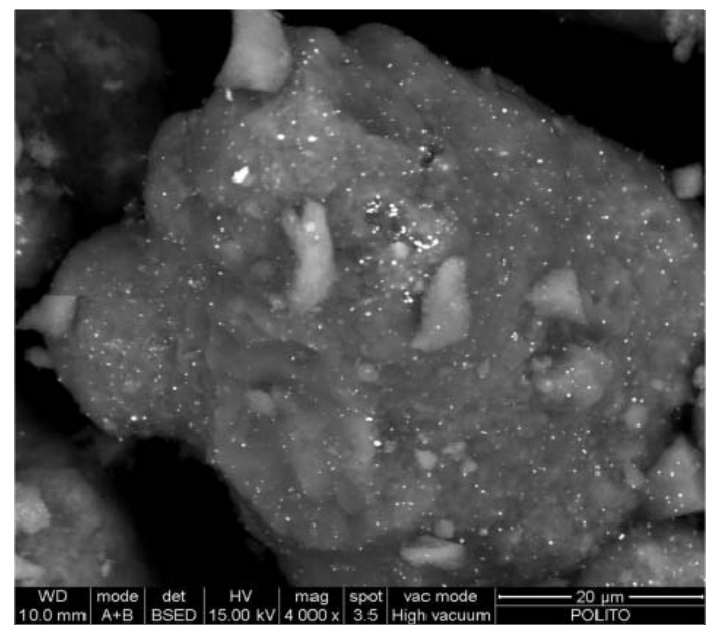

Figure 2: SEM view of 2 wt\% $\mathrm{Pt}$ ( recovered) $/ \mathrm{Al}_{2} \mathrm{O}_{3}$ with a magnification of $4 \mathrm{KX}$

An higher platinum cluster average diameter was observed for the $2 \mathrm{wt} \% \mathrm{Pt} / \mathrm{Al}_{2} \mathrm{O}_{3}$ commercial sample (not reported).

The catalytic activity tests (Fig. 3) concerning the carbon combustion showed that the $2 \mathrm{wt} \% \mathrm{Pt}\left(\right.$ recovered) $/ \mathrm{Al}_{2} \mathrm{O}_{3}$ exhibited a slightly higher peak combustion temperature $\left(\mathrm{T}_{\mathrm{p}}=561^{\circ} \mathrm{C}\right)$ compared with the commercial $2 \mathrm{wt} \%$ $\mathrm{Pt} / \mathrm{Al}_{2} \mathrm{O}_{3}\left(\mathrm{~T}_{\mathrm{p}}=555^{\circ} \mathrm{C}\right)$. Shifting our attention towards the
NO oxidation to $\mathrm{NO}_{2}$, both catalysts showed a similar performance, reaching the highest conversion ( 61\%) at $310^{\circ} \mathrm{C}$ with no production of nitrous oxide. The residual part of solution deriving by Pt recovering from a spent DOC converter has been calcined at $400^{\circ} \mathrm{C}$ and characterized by an FESEM-EDS analysis. The EDS result brings out the presence of pure Platinum. No other elements were observed.

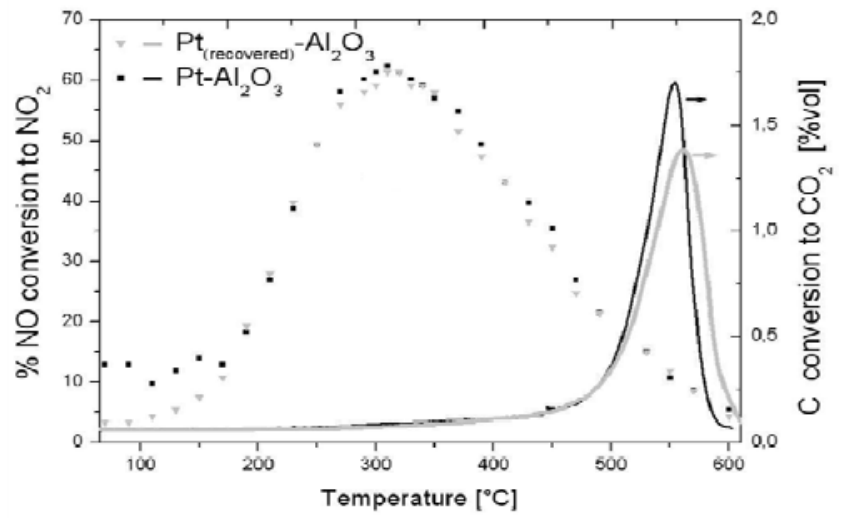

Figure 3: Activity results regarding the $C$ conversion to $\mathrm{CO}_{2}$ and $\mathrm{NO}$ conversion to $\mathrm{NO}_{2}$

\section{Conclusions}

The work has established the catalytic activity towards soot combustion and NO oxidation of platinum recovered from a spent DOC. The activity results were quite similar to the commercial and fresh Pt- $\mathrm{Al}_{2} \mathrm{O}_{3}$ catalyst. The SEMEDS analysis has demonstrated that the morphology of this platinum could be interesting for a new utilization and confirmed the strength relationship between chemiphisical properties and catalytic activity. Further studies are necessary to complete the scenario for a right recycling of spent after-treatment devices

\section{References}

(1) Benson, M.; Bennett, C. R.; Harry, J. E.; Patel, M. K.; Cross, M. The recovery mechanism of platinum group metals from catalytic converters in spent automotive exhaust systems. Conservation and recycling 2000, 1, 31.

(2) Barakat, M. A.; Mahmoud, M. H. H. Recovery of platinum from spent catalyst. Hydrometallurgy 2004, 72, 179.

(3) Gaita, R; Al-Bazi, J. An ion-exchange method for selective separation of palladium, platinum and rhodium from solutions obtained by leaching automotive catalytic converters. Talanta 1995, 42, 249.

(4) Cauda, E.; Fino, D.; Saracco, G; Specchia, V. Nanosized Pt-perovskite catalyst for the regeneration of a wall-flow filter for soot removal from diesel exhaust gases. Topics in Catalysis 2004, 30/31, 299. 